Volume 41

Issue 1 Dickinson Law Review - Volume 41, 1936-1937

10-1-1936

\title{
Liability of the Husband for the Torts of His Wife
}

Charles M. Koontz

Follow this and additional works at: https://ideas.dickinsonlaw.psu.edu/dlra

\section{Recommended Citation}

Charles M. Koontz, Liability of the Husband for the Torts of His Wife, 41 Dick. L. REv. 55 (1936).

Available at: https://ideas.dickinsonlaw.psu.edu/dlra/vol41/iss $1 / 6$

This Article is brought to you for free and open access by the Law Reviews at Dickinson Law IDEAS. It has been accepted for inclusion in Dickinson Law Review by an authorized editor of Dickinson Law IDEAS. For more information, please contact lja10@psu.edu. 
child, she is entitled to its earnings. ${ }^{37}$ Likewise, it has been decided that a widowed mother has a right of action, under the statutes in question, for loss of services of her minor child and the expenses of his illness. ${ }^{38}$ So also may a deserted mother sue in her own right and name. ${ }^{39}$ Finally there remains the Act of 1893 , P. L. $344^{40}$ which allows a wife the right to recover for a tort committed upon her as the action is her separate property. An action under this Act cannot be interfered with or controlled by the husband. If the tort is separate, ${ }^{41}$ a separate action is brought by the wife; but if the injury is of such a nature that it falls within the statutes already referred to, then the wife still has a right to sue for the wrong done to her but the husband may join if he wished to assert his claim. Having noted these additional situations, our numerical list will then be completed thusly:

(e) Action by the wife in her own name and in the infant's name to recover for her child and in her own right where she supports the child without aid of the father and where she is of a good character.

(f) Action by the wife in her own name and right when the injury sustained is of such a character as not to fall within the Act of 1895 , P. L. 54 .

Louis C. Glasso

\section{LIABILITY OF THE HUSBAND FOR THE TORTS OF HIS WIFE}

Since its acknowledgment as a part of the Pennsylvania common law, great changes have been wrought in the law regarding the husband's liability for the torts of his wife. Today, by interpretation of the various statutes, the husband's liability has been so reduced as to render it of little importance. In order, however, to show the magnitude of these changes, it is necessary to discuss the principles which were followed by our courts until about fifty years ago.

87Note 33, cited supra; Matthews v. Koch, 20 C. C. 363 (1898) that this act applies only to minor children and that in the absence of an express contract for services, a married woman cannot recover for the seduction of an adult daughter.

38Windle v. Davis, Director-General, 275 Pa. 23 (1922) construing the Act of 1911, P.L. 177 which has been repealed and partly re-enacted by the Act of 1925, P.L. 638 .

39Note 33, cited supra.

4048 P. S. 31.

11 Fero v. Contreaso, 13 Dist. 394 (1904) that a libel on the wife is a separate injury to her capable of being redressed by an action in her Qwn name and right. Walker v. Phila., $195 \mathrm{~Pa}$. 168 (1900). 
Until a comparatively recent date, the husband was liable for almost all of the torts of his wife whether committed before or during coverture. ${ }^{1}$ He was liable whether he was present or absent at the time of the commission of the tort, ${ }^{2}$ and whether he knew that the tort was to be committed or was in complete ignorance of it until after its commission. ${ }^{3}$ The idea was carried to such an extreme that, although the wife could not be arrested for her torts, the husband was liable to be arrested for them. ${ }^{4}$ Blackstone states this principle in the words that "if judgment be recovered against husband and wife for the contract, nay even the personal misbehavior, of the wife during coverture, the capias shall issue against the husband only; which is one of the great privileges of the English wives." 5 In Pennsylvania, the wives enjoyed this privilege also.

There were some-exceptions to this liability on the part of the unfortunate male. He was not liable for what the courts termed "torts compliciter," 6 that is, torts arising from the invalid contracts of the wife. This exception is explained in Keen $\nu$. Hartman ${ }^{7}$ in the following words: "the real injury flows from her non-compliance with her engagement, and an action to recover compensation for it, if maintainable, gives equal effect to her contract, no matter in what form the action may be brought, whether in form ex contractu or ex delicto. It practically enforces it." Or, in the words of the great English judge, Pollock: ". . . when the fraud is directly connected with the contract of the wife, and is the means of effecting it, and parcel of the same transaction, the wife cannot be responsible, and the husband be sued for it together with the wife. If this were allowed it is obvious the wife would lose the protection which the law gives her against contracts made by her during coverture, for there is not a contract of any kind which a feme covert could make whilst she knew her husband to be alive, that could not be treated as a fraud. For every such contract would involve in itself a representation of her capacity." 8 Another exception to the general rule was the case in which the wife committed the tort before marriage, and while the wife of another man. Here the courts have held that the second husband is not liable. ${ }^{9}$

Married women's torts fall into two classes, ante-nuptial and post-nuptial torts. It is well settled that in order to hold the husband liable for the ante-

\footnotetext{
1Deardorff v. Pepple, 36 Pa. Super. 224 (1908); Overholt v. Ellswell, 1 Ashm. 200 (1831); Turner and Co. v. Belles, $15 \mathrm{~Pa}$. Dist. 973 (1906).

2Wheeler and Wilson Mfg. Co. v. Heil, 115 Pa. 487, 8 Atl. 616 (1887); Hess v. Heft, 3 Pa. Super. 582 (1896); Deardorff v. Pepple, supra.

3 See cases cited in note 2.

4See Vocht v. Kuklence, 119 Pa. 365 (1888).

5Quoted in Vocht $v$. Kuklence, supra.

6Keen v. Hartman, $48 \mathrm{~Pa} .597$ (1865).

7 See cases cited in note 6 .

8 Keen v. Coleman, $39 \mathrm{~Pa} .299$ (1861).

9There is no Pennsylvania case on point, but see Culmer v. Wilson, 13 Utah 129, 44 Pac. 883 (1896).
} 
nuptial torts of the wife, the marriage must have been de jure. ${ }^{10}$ Corpus Juris, ${ }^{11}$ however, states that a de facto marriage is sufficient to hold the husband liable for the post-nuptial torts of the wife. In justification of this statement Overbolt $\nu$. Ellswell ${ }^{12}$ is cited. This case, on the contrary, appears to hold the direct op. posite. It points out that the reason for holding the husband liable for the contracts of his wife when the marriage is only de facto is that "he gives her credit with the world, by holding out such pretence, and it can not be endured, that he should afterwards shelter himself from answering for confidence bestowed on her, which never would have been imparted but for his own improper conduct. The law, therefore, stops him from denying his marital obligations, because, it is fraudulent and against good faith, under such circumstances, to set up such a defense." This reasoning is applicable to contract cases, but it is obvious that it is no justification for a similar rule in torts. For example, if $W$, the de facto wife of $H$, silently steals up behind $A$ and strikes him with a rolling pin, how can it be seriously considered that $A$ permitted this battery in reliance on the fact that $\mathrm{H}$ holds out $\mathrm{W}$ as his wife? Certainly the court, in giving the reason for the rule in contracts, was, by implication, rejecting such a rule in torts. Another case cited by Corpus Juris ${ }^{11}$ was a case of contract which, according to the reasoning of Overbolt $v$. Ellswell, 12 is based upon an entirely different principle. The third and last case cited in defense of this proposition was a case of breach of trust in which the problem is not discussed. It is, therefore, quite possible that the Pennsylvania courts would have required a de jure marriage necessary in order to impose liability upon the husband for the post-nuptial as well as the antenuptial torts of the wife, if such a case had ever arisen.

The ante-nuptial torts of the wife presented little or no problem to the courts. The husband was absolutely liable with the one exception noted above. However, if an action had been started against the wife while she was still a feme sole, this action was continued against her alone and it was not necessary that the husband be joined. ${ }^{13}$

On the other hand, a number of problems arose in the case of post-nuptial torts. It might be necessary to decide the liability of the husband for a tort committed in the husband's absence but at his command, or in his absence and without any knowledge on his part that a tort was going to be committed. Or, again, he might have been present but took no part in the proceedings, or he might have been present and commanded the doing of the act.

\footnotetext{
10 Overholt v. Ellswell, supra.

1130 Corpus Juris 784 . See also note 28 which cites cases in defence of the proposition.

12 Overholt v. Ellswell, supra.

13Hawk v. Harman, 5 Binney 42 (1812).
} 
It was well settled that the husband was liable jointly with the wife for the torts of the wife committed in his absence and without any coercion on his part. ${ }^{14}$ These included ante-nuptial torts. ${ }^{15}$ The husband was joined with the wife in these suits if brought during coverture. ${ }^{16}$ If, however, the wife died before the action had been reduced to a judgment, the action abated. ${ }^{17}$ On the other hand. if the husband died 18 or a divorce a vinculo ${ }^{19}$ was secured, the action was con. tinued against the wife alone.

The doctrine of marital coercion has long stood and, in some instances, still stands in good repute with the law. It has been used with much vigor by the courts in applying the law of torts. If the wife commits a tort in the presence and at the command of the husband, he alone is liable. ${ }^{20}$ The mere presence of the husband is sufficient to raise a presumption of coercion ${ }^{21}$ and, unless it is shown that the wife acted of her own free will or was the principal actor, the husband is the only one against whom an action will lie. ${ }^{22}$

The question which arises when the husband is absent but commands the commission of the tort has never been decided in Pennsylvania. A number of the cases quote Kent's Commentaries, ${ }^{22 *}$ that "the husband is liable for the torts of the wife during coverture; if committed in her company, and by his order, he alone is liable; if not, they are jointly liable, and the wife must be joined in the suit with her husband." 23 This would seem to indicate that there is joint liability when the husband is absent but coercing. The cases also cite (for another rule of law) the New York case of Cassin y. Delany" which held that "an offense by his (husband's) direction, but not in his presence, does not exempt her from liability." Other Pennsylvania cases seem to hold that the command of the husband is sufficient to relieve the wife of liability. ${ }^{25}$ This, however, is probably due to careless choice of words rather than an expression of the opinion of the court. In view of the language of the majority of the cases and the authorities

14Franklin's Appeal, 115 Pa. 534 (1886); Deardorff v. Pepple, supra; Hess v. Heft, supra.

15 See Hawk v. Harman, supra.

16 See cases cited in note 14 , supra.

17Franklin's Appeal, supra; Overholt v. Ellswell, supra.

18 See cases cited, note 17.

19 Whitehouse v. Wisser, 40 Pa. Co. 463 (1913).

20 Wheeler and Wilson Mfg. Co. v. Heil, supra; Franklin's Appeal, supra; Hess v. Heft, supra; Adams v. Derian, 115 Pa. Super. 357 (1934); Quick v. Miller, 103 Pa. 67 (1883).

21 Wheeler and Wilson Mfg. Co. v. Heil, supra; Franklin's Appeal, supra; Hess v. Heft, supra.

22 Hess v. Heft, supra; Deardorff v. Pepple, supra; Adams v. Derian, supra; Wheeler and Wilson Mig. Co. v. Heil, supra; Fendall v. Eckert, 90 Pa. Super. 305 (1927).

$22 *$ Volume 2, p. 149.

${ }^{23}$ Franklin's Appeal, supra; Wheeler and Wilson Mfg. Co, v. Heil, supra.

24 Cassin v. Delany, 38 N. Y. 178 (1868).

${ }^{26}$ Hess v. Heft, supra; Deardorff v. Pepple, supra; O'Connor v. Welsh, 29 W.N.C. 92 (1891). 
cited, Pennsylvania will probably be in accord with the Massachusetts case of Handy $v$. Foley, ${ }^{26}$ which held that the husband and wife were both jointly liable.

Thus far we have been dealing with the law without giving any reasons why the husband should be imposed on to such an extent. Pennsylvania cases give only two of the many reasons offered by other courts. These two are: (1) that the husband became absolute owner of all the wife's personal property and had the right to receive her earnings and the rents and profits of her real estate;27 (2) that the wife could not be sued alone. ${ }^{28}$ The passage of two statutes in the nineteenth century has effectively removed these reasons.

The act of $1848^{29}$ gave the wife ownership of her property as fully after marriage as before, and did not protect it from levy and execution on any judgment recovered against the husband for the torts of his wife, providing that in such cases execution shall be first had against the property of the wife. ${ }^{30}$ The Pennsylvania courts held that this act did not abrogate the common law rule ${ }^{31}$

The act of $1887^{32}$ declared that a married woman shall be capable of being sued and that her husband need not be joined with her. The case of Hinski $\nu$. Stein, ${ }^{33}$ decided under a later statute, says of the act of 1887 , "we are unable to see how that statute could be administered according to its letter or its spirit, were we to hold that the common law doctrine, to which we have referred, is still in active operation." However, the effect that this statute might have had on the Pennsylvania courts is theoretical merely because the act of $1893^{34}$ was passed and repealed the act of 1887 .

The act of 1893 stated that "hereafter a married woman may sue or be sued civilly in all respects and in any form of action with the same effect and results and consequences as an unmarried person." The cases immediately following the passage of this act held that the common law rule had not been abrogated. ${ }^{34 *}$ It was not until the case of Gustine $v$. Westenberger, ${ }^{35}$ decided in 1909 , that the courts decided that the legislature, by implication, had discarded the ancient rulc. This is an interesting case because, although followed by the subsequent cases and considered as an authority, the case itself made the ruling merely by way of dictum and gave no reasons whatsoever for making such a drastic change. It

26Handy v. Foley, 121 Mass. 259 (1876).

27Overholt v. Ellswell, supra; Hawk v. Harman, supra; Quick v. Miller, supra; Hinski v. Stein, $68 \mathrm{~Pa}$. Super. 441 (1917).

28Deardorff v. Pepple, supra; Hawk v. Harman, supra.

291848 , P.L. 336.

30Deardorff v. Pepple, supra.

31 Quick v. Miller, supra.

32 1887, P.L. 333.

38Hinski v. Stein, supra.

341893. P.L. 344.

34"Ridgway v. Speilman, 20 Pa. Co. 596 (1898) ; Hess v. Heft, supra; Deardorff v. Pepple, supra. 35Gustine v. Westenberger, $224 \mathrm{~Pa}$. 455 (1909). 
might almost be considered as the perfect example of a court following the advice of Lord Mansfield to a newly appointed judge-.". . . never give any reasons for your decisions. Your decisions may be right, but your reasons are sure to be wrong."

There has been some criticism of this complete change of position of the court and it might be well to look at this matter briefly. Pennsylvania has given only two reasons for the rule, as has already been pointed out. The possibility that these reasons were not the ones originally responsible for the rule has been the foundation of the argument against changing the rule. ${ }^{36}$ It has always been the policy of the Pennsylvania courts to adopt only those principles of the common law which were applicable to this country. If, then, they adopted a common law rule it would be only for the reasons which they give and these reasons become the real reason for the rule in Pennsylvania. It would appear to be illogical, therefore, to say that the common law liability of the husband for the torts of his wife should not have been abrogated when it is obvious that the reasons given by the Pennsylvania courts no longer exist. In all fairness it should be conceded that the familiar maxim of cessant ratione legis cessat et ipsa lex has been properly applied.

Thus, today, in the movement for freedom of the weaker sex from their ancient bonds, we find that the poor, misguided husband has indirectly been benefited by being relieved of one of his most unjust liabilities. Not one bit of his general liability for his wife's torts remains on the pages of the Pennsylvania decisions.

There is one remaining form of liability which is generally classified with the husband's liability for the torts of the wife, and that is the liability for torts committed by the wife under the coercion of the husband. Strictly speaking, however, these are the torts of the husband alone. The wife is neither joined in the suit nor considered in any way responsible..$^{37}$ In the eyes of the bachelor, the law, she is an innocent tool in the hands of her husband.

This doctrine of coercion was not thrown aside by the courts with the rest of the husband's tort liability. Today, the wife is considered as much susceptible to masculine influence as she was centuries ago.

Two elements must be considered in applying this rule of law. The husband must (1) be present, and (2) he must command the act or its omission. Exactly what is embraced by these elements cannot be explained as there has been no discussion of them nor any cases requiring a careful consideration of them. Perhaps some future decision will define what is necessary to constitute "presence,"

36University of Pennsylvania Law Review 74:305. For a discussion of the reasons for the husband's liability for the torts of his wife, see University of Pennsylvania Law Review 83:66 and University of lowa Law Review 18:30.

87 Hess v. Heft, supra; Hinski v. Stein, supra; Adams v. Derian, supra. 
or what is meant by the word "command," but, until then, the nature of these elements must remain in complete obscurity.

Another venture into the realm of the psychology of married life gives rise to the presumption of coercion which the courts apply when the husband is merely present. If the husband is present when the tort is committed, there is a presumption that the wife acted under his coercion. ${ }^{38}$ Now, if the law is to be uniform, there is a presumption that the husband merely commanded the doing of the act. ${ }^{39}$ Hence, the proof that there was no coercion should be very difficult. The Pennsylvania courts have held that it must be proved that the wife acted of her own free will and that she was the principal actor. ${ }^{40}$ Yet, the evidence which has been held to be sufficient to rebut the presumption of coercion has not been very strong. In Adams v. Derian, ${ }^{41}$ the wife owned an apartment house and the plaintiff was a tenant. The husband, in the presence of the wife, committed an assault upon the plaintiff in an effort to collect some rent. The court states that the husband was acting as the wife's agent and, since she made no objection and apparently assented to her husband's assault, this would be sufficient evidence to rebut a presumption of coercion when the wife later committed an assault upon the plaintiff in the presence of the husband. This seems to be very little evidence when one considers that to relieve the wife of entire liability she need only show that her husband commanded her to do the act. However, there are so few cases of this nature in Pennsylvania that it is uscless to attempt to foretell just what evidence will be deemed sufficient to rebut the presumption of coercion. The court should, at any rate, demand very positive proof that the wife did act of her own free will if the presumption is to correspond at all with the element for which it is substituted.

In a final analysis it is evident that taking a wife is, today, from a legal viewpoint, not nearly so serious a proposition as it was prior to 1909 . Of course, the husband is still liable for torts committed under his coercion, but even this has its bright side-here is one place where the hen-pecked husband is at least prima facia the head of the family.

Charles M. Koontz

38 See cases cited in note 21.

39 Since the husband's presence is required in order for the presumption to apply, the presumption must refer to the other element of coercion, i.e., command.

40 See note 22.

4 Adams v. Derian, supra. 